\title{
THE MECHANISM OF GLYCYRRHIZA EXTRACT AND ITS APPLICATION IN POULTRY PRODUCTION
}

Bordunova Olga Georgievna

Doctor of Agricultural Sciences, Proffesor

Sumy National Agrarian University

ORCID: 0000-0002-7120-1040

E-mail: bordunova.olga59@gmail.com

Vechorka Victoria Viktorivna

Doctor of Agricultural Sciences, Professor

Sumy National Agrarian University ORCID: 0000-0003-4956-2074

E-mail: vvvechorka@gmail.com

\author{
Liu Changzhong \\ Doctor of Agricultural Sciences, Professor \\ Henan Institute of Science and Technology of China \\ ORCID: 0000-0002-7014-4486 \\ e-mail: 15103733474@163.com \\ Kyselov Oleksandr Borisovich \\ $\mathrm{PhD}$, Associate Professor \\ Sumy National Agrarian University \\ ORCID https://orcid.org/0000-0003-0134-7893 \\ email: oleksandr.kyselov@snau.edu.ua \\ Samokhina Evgeniya Anatoliyivna \\ $\mathrm{PhD}$, Associate Professor \\ Sumy National Agrarian University \\ ORCID: 0000-0002-0983-3047 \\ E-mail: evgeniya_samokhina@ukr.net
}

The article presents studies of the effect of phytogenic preparations on the immune system and productivity of agricultural animals. Analysing the growing interest in the world in phytogenic drug, the article presents studies of the most popular herbal medicines- glycyrrhiza. This drug is one of the components of traditional Chinese medicinal herbs. Glycyrrhiza has the functions of invigorating qi and strengthening the spleen, expectorating phlegm and relieving cough and pain, clearing heat and detoxification, and reconciling the properties of medicine. Traditionally, this drug has been used for the prevention and treatment of humans as antitumor, anti-inflammatory, anti-viral, liver protection, skin care. It is known that glycyrrhiza residues in animal products do not have side effects on the human body, and this fact draws even more attention to the wider use of glycyrrhiza in modern animal husbandry. However, some of the active components of glycyrrhiza, at the moment, are not fully research. The extraction process is also being studied. The mechanism of disease resistance and treatment with this drug are currently not very clear. As a result, the drug is not widely used in animal husbandry and poultry farming. Glycyrrhiza contains triterpene saponins, flavonoids, polysaccharides and other biologically active substances that are beneficial to the body. Possessing a complex of unique properties, such as: antioxidant, antibacterial, antiviral, antitumor, anti-inflammatory, as well as the ability to regulate the immune and biological activity of the body, control blood sugar levels, it is increasingly attracting attention to itself. This article reviews the chemical composition, mechanism of action and application of glycyrrhiza in poultry production, in order to provide a reference for the application of glycyrrhiza extract in poultry production.

Key words: glycyrrhiza extract, phytogenic preparations, antioxidant, antibacterial, antiviral, antitumor, anti-inflammatory, productivity, poultry.

DOl: https://doi.org/10.32845/bsnau.lvst.2021.2.8

Glycyrrhiza is the dried roots and stems of legumes Glycyrrhiza uralensis Fisch, Glycyrrhiza inflate Bat, and Glycyrrhiza glabra L. It has excellent characteristics such as cold resistance, heat resistance, drought resistance, and salt-alkali resistance. It is a perennial legume herb and a commonly used Chinese medicinal material which is sweet in nature, flat in taste, and has the effects of invigorating the spleen and qi, clearing away heat and detoxification, eliminating phlegm, re-

lieving cough and pain, and reconciling various drugs [1]. Glycyrrhiza is rich in chemical substances with biological activity, mainly triterpene saponins (mainly glycyrrhizic acid), flavonoids, coumarins, alkaloids, volatile oils, organic acids, sugars, etc. Currently, there are many studies on the effective ingredients of glycyrrhiza such as glycyrrhizic acid, glycyrrhetinic acid, glycyrrhiza polysaccharides and glycyrrhizin flavonoids. Glycyrrhizic acid is the main triterpenoid active ingredient in glycyr- 
rhiza. Its main function is anti-tumor, anti-inflammatory and antivirus [2].

\section{The chemical composition of glycyrrhiza}

Glycyrrhiza mainly contains triterpene saponins, flavonoids, polysaccharides, coumarins, volatile oils and amino acids, among which triterpenoids and flavonoids are its main components [3].

1.1 Triterpene saponins: There are more triterpene saponins in the roots and rhizomes of glycyrrhiza, such as glycyrrhizic acid, glycyrrhetinic acid, glycyrrhizin and isoglycyrrhizin, etc. Glycyrrhizic acid and its salts are collectively referred to as glycyrrhizin Su (glycyrrhizin, GL). The content of glycyrrhizic acid is an important parameter that determines the quality of glycyrrhiza herbs.

1.2 Flavonoids: glycyrrhiza contains a variety of flavonoids, mainly flavonoids, flavonols, chalcones, isoflavones, dihydrochalcones, dihydroflavonoids, etc. Flavonoids mainly include glycyrrhizin, glycyrrhizin, isoliquiritin, and isoliquiritin.

1.3 Polysaccharides: glycyrrhiza contains a variety of polysaccharide compounds, including: glucan, rhamnose, galactose, arabinose and so on.

1.4 Other ingredients: In addition to the above ingredients, glycyrrhiza also contains a small amount of coumarins, volatile oils, stilbene, sterols, organic acids, amino acids, etc. [4].

\section{glycyrrhiza}

2. The mechanism of the chemical components of

Glycyrrhiza belongs to the tonic Chinese herbal medicine. It has the functions of replenishing the qi, relieving emergency and relieving pain, clearing away heat and detoxification, relieving cough and expectorating, and reconciling various medicines. From the perspective of modern medicine, glycyrrhiza has a variety of medicinal effects, including anti-tumor, anti-oxidation, anti-inflammatory, anti-viral, immune regulation, lowering blood sugar and lipids, protecting liver and skin care, etc. [5].

\subsection{Anti-tumor}

The anti-tumor effect of glycyrrhiza is mainly manifested in regulating the body's immunity, blocking the cell cycle, and inducing cell apoptosis. The research on the anti-tumor effect of glycyrrhiza mainly includes anti-prostate cancer, breast cancer, myeloma, gastric cancer, liver cancer, lung cancer and cervical cancer. Research by Seon M R et al. [6] showed that isoangustone $A$, an active ingredient extracted from glycyrrhiza can inhibit DNA synthesis, induce human prostate cancer cells DU145 and mouse breast cancer cells 4T1 cell cycle arrest in G1 phase, and reduce cell cycle proteins. The expression of cycLinA and cycLin D1 inhibits the expression of proliferating nuclear cell antigen and the expression of cyclin-dependent kinase (CDK2) and CDK4 protein in tumor tissues. Xu Shumei et al. [7] found that glycyrrhetinic acid GA had a certain inhibitory effect on the proliferation of myeloma U266 cells, and its inhibitory effect is mainly manifested in time and concentration dependence. Lee CS[8] has shown that 18ß-glycyrrhetinic acid can increase the lethality of human cervical cancer SiHa cells and has a positive effect on the treatment of cervical cancer. Xiao et al. [9] found that glycyrrhiza chalcone A could increase the expression of $\mathrm{Rb}(\mathrm{C}-15)$ in human gastric cancer cell lines MKN-28, AGS and MKN-45, and reduce cyclin A, cyclin B and mouse double microgene (MDM2) expression, thereby inhibiting the proliferation of gastric cancer cells.
Studies have shown that glycyrrhiza extract can inhibit the proliferation of breast cancer cells MCF-7 by increasing the expression of tumor suppressor genes p53 and p27 and reducing the expression of cell cycle-related genes [10]. Glycyrrhizin is a compound called dihydroflavonoid monomer extracted from glycyrrhiza. Studies have found that glycyrrhizin can inhibit the invasion and metastasis of human melanoma A375 cells by upregulating the gene expression levels of PTEN and TIMP2, down-regulating the expression of Matrix Metalloproteinase2 (MMP2) protein, and obstructing the p-AKT signaling pathway [11]. Glycyrrhizin plays an anti-tumor effect by inhibiting vascular endothelial growth factor (VEGF) and is expected to treat cervical cancer [12]. Glycyrrhizin can also reduce the expression of matrix metalloproteinase-2 by inhibiting the PI3K/Akt signaling pathway [13]. Isoliquiritin also has the effect of inducing apoptosis of human gastric cancer cells MGC-803 [14].

Glycyrrhiza flavonoids have obvious anti-tumor effects on human liver cancer cells (H22) and sarcoma180 (S180), and the combination with cyclophosphamide has obvious synergistic and attenuating effects [15]. Glycyrrhiza polysaccharides may inhibit the growth of solid tumors and prolong the survival period of mice with ascites tumors by affecting the expression of $\mathrm{Bcl}-2$, p53 and bax gene proteins [16]. Xie et al. [17] found that glycyrrhizin in Hela cells inhibited the growth of tumor cells by inhibiting the activity of HIF-1a and down-regulating the expression of VEGF. The above research results indicate that glycyrrhiza has an inhibitory effect on tumor cells, plays an active role in antitumor, and is a potential interfering agent that hinders cancer progression.

\subsection{Antioxidant}

Oxidative damage is closely related to the occurrence and development of tumors. In many tumor hypoxia tolerance environments, hypoxia inducible factor 1 (HIF-1) protein degradation pathway is inhibited, the level of HIF-1 protein in the nucleus increases, and the expression of downstream genes such as vascular endothelial growth factor VEGF is enhanced, which is conducive to tumor cell growth, invasion and metastasis [18]. Studies have shown that glycyrrhiza polysaccharides can prevent oxidative damage in the body by optimizing the body's defense system to prevent oxidation, so as to achieve the purpose of anti-oxidation [19]. Conkinson et al. [20] showed that glycyrrhizin could improve the activity of oxidases such as glutathione peroxidase (GSH-Px) and superoxide dismutase (SOD), as well as malondialdehyde (MDA) and other lipid oxidation metabolites, and remove free radicals in the brain and inhibit lipid peroxidation in the brain [21]. The experiment of Lian Yijun et al. [22] showed that glycyrrhiza polysaccharide could scavenge DPPH free radicals and hydroxyl free radicals, and had strong antioxidant activity. Isoliquiritin and glycyrrhizin have certain scavenging effects on hydroxyl free radicals, superoxide anions and DPPH [23]. The experiment of Xue Wei et al. [24] showed that the scavenging ability of glycyrrhiza polysaccharides on $\mathrm{DPPH}$ free radicals, $\cdot \mathrm{OH}$ free radicals, $\mathrm{O}^{2-}$. free radicals and ABTS increased with the increase of the concentration of glycyrrhiza polysaccharides. When the concentration of glycyrrhiza polysaccharide reaches $3 \mathrm{mg} / \mathrm{mL}$, the scavenging ability of $\mathrm{DPPH}$ free radicals, $\mathrm{OH}$ free radicals, $\mathrm{O}^{2-}$. free radicals and ABTS are $50.75+0.13 \%, \quad 52.32+0.13 \%, \quad 25.84+0.35 \%$, $44.57+0.15 \%$, respectively. Glycyrrhiza polysaccharide can effectively inhibit a-glucosidase activity. As the concentration of glycyrrhiza polysaccharide increases, the ability to inhibit a- 
glucosidase increases. When the concentration of glycyrrhiza polysaccharide reaches $6 \mathrm{mg} / \mathrm{mL}$, its inhibition rate of $a$ glucosidase activity reached $64.77 \%$.

\subsection{Protect the liver}

Normal cells maintain the integrity of cell physiological functions in a normal oxygen physiological state. Tumors, especially solid tumor cells, adapt to hypoxia tolerance to maintain tumor development and deterioration. Hypoxia can promote occurrence of malignant biological behaviors of the growth, infiltration and metastasis of solid tumor cells [18]. Studies have shown that glycyrrhiza can reduce the liver damage caused by dioscorea opposita by regulating oxidative stress and inhibiting liver and protein expression, and it is related to the time of drug administration [25]. Glycyrrhizin is produced by the deglycosidation of glycosides in glycyrrhiza. The experiment of Zhang Yiping [18] showed that the effective part of glycyrrhizin could effectively inhibit the activity of human liver cancer cells, and down-regulate the hypoxia signal HIF1 $\beta$ and its downstream target gene VEGF. The expression level is not conducive to the malignant progress of liver cancer cell SMMC7721. At the same time, glycyrrhizin can regulate the biological behaviors related to liver cancer Hep G2 cell apoptosis. Further studies have shown that glycyrrhizin promotes antioxidant enzyme activity and inhibits oxidation metabolism and restores mitochondrial pathways of anti-apoptotic genes, inhibits inflammation and fibrosis, thereby preventing chronic liver injury and malignant transformation in rats caused by the carcinogen $\mathrm{CCl} 4$ through the PGC-1a pathway. Nrf2 is a key transcription factor that induces antioxidant enzymes. Kim et al. [26] reported that glycyrrhizin could prevent liver lipid degeneration and antioxidant damage by activating Nrf2.

At present, the treatment of hepatitis is mainly achieved through anti-virus, inducing interferon, regulating body immunity, and anti-inflammatory effects. Glycyrrhizin can directly fight hepatitis virus and induce interferon, increase the activity of NK cells and inhibit hepatitis virus [27]. Clinically, glycyrrhizic acid preparations have glucocorticoid-like effects, can reduce the infiltration of inflammatory cells, inhibit the release of various inflammatory mediators, and have membrane stabilization. They are commonly used drugs for anti-inflammatory and liver protection, and the magnesium isoglycyrrhizinate present in natural glycyrrhizic acid ( Magnesium isoglycyrrhizinate, MglG) can significantly improve liver function and reduce the degree of liver fibrosis [28]. Experimental and clinical studies have shown that glycyrrhizin diamine and compound glycyrrhizin have a preventive effect on liver injury, and are of great significance for the early prevention of the development of chronic hepatitis $B$ to cirrhosis [29,30,31]. The research results of Liang et al. [32] showed that glycyrrhiza polysaccharide could effectively alleviate the acute liver injury induced by CCL4 in mice, and reduce serum Alanine Transaminase (ALT), Aspartate aminotransferase (AST), Alkaline Phosphatase (ALP), Lactate Demineralization Hydrogenase (LDH) activities and mutations of caspase-3, TGF- $\beta 1$ and TGF- $\beta 1$ mRNA and have a hepatoprotective effect. Chen Yunhua et al. [33] found that isoliquiritin had the effect of protecting the liver. The total flavonoids of glycyrrhiza may be able to interfere with non-alcoholic fatty liver by activating AMPK signaling molecules [34]. Glycyrrhetinic acid is the aglycone of glycyrrhizin, which has biological activities such as liver protection, detoxification and antioxidant, and can obviously promote the apoptosis of liver cancer cells. [2] Diammonium glycyrrhizi- nate has a significant effect on reducing the ALT of patients with chronic viral hepatitis. After intravenous administration, more than $85 \%$ of patients' ALT decreased significantly and returned to normal, and it has a preventive effect on liver damage caused by various hepatotoxic agents [35]. The results of these studies all show that glycyrrhiza extract can be used as an effective drug for improving liver function and health.

\subsection{Immune regulation}

Glycyrrhizic acid is an effective biological response modifier, and its immune function is manifested in many aspects such as immunocompetent cells, cytokines, complement and so on. Glycyrrhizin can enhance the proliferation and activity of helper T lymphocytes, promote the production of IL-2, IFN-y, IL1 and other cytokines by lymphocytes, and inhibit the production of IL-4, IL-10, IL-8, etc. At the same time, it has complement activity and can selectively inhibit the activation pathway of the complement system [36].

Glycyrrhiza polysaccharides play an immunomodulatory effect mainly by activating the body's immune system [37]. Wang Lirong et al. [38] showed that glycyrrhiza polysaccharide could significantly increase the weight of mice and increase the formation rate of E2 rosettes of lymphocytes, thereby improving cellular immune function. Hong et al. [39] studied the effect of glycyrrhiza polysaccharide on the proliferation of spleen lymphocytes and serum antibody levels in mice with a high-fat diet, and found that glycyrrhiza polysaccharide could promote the proliferation of mouse spleen lymphocytes and increase the levels of various antibodies in serum. Li Fasheng et al. [40] used ovalbumin to stimulate the immune response of mice, then administrated the mice with glycyrrhiza polysaccharide, and then stimulated the body's immune system with the same antigen. The results show that both $50 \mathrm{mg} / \mathrm{L}$ and $100 \mathrm{mg} / \mathrm{L}$ of glycyrrhiza polysaccharide could increase the immune response level of mice and the level of cytokine IFN-y. The aqueous extract of glycyrrhiza contains abundant high-stability miRNAs, which can affect the growth status of human immune cells in vitro, and the abundance miRNA156 does have a certain effect on the expression of immune cell-related genes[41]. Glycyrrhiza extract isoliquiritin and cortexin can promote the activity of regulatory $T$ cells in vivo and in vitro, and can reduce the colitis induced by Dextran Sulfate Sodium Salt (DSS) in mice by exerting an immunosuppressive effect [42].

\subsection{Anti-inflammatory}

Inflammation is a defense response of the body and the initial cause of many chronic diseases. Inflammation is caused by a variety of inflammatory factors released in the process of inflammation, which can be divided into infectious inflammation and aseptic inflammation. Kim et al. [43] found that isoliquiritin can achieve anti-inflammatory effects by inhibiting the expression of IKK, ERK1/2 enzymes, p38 phosphorylation, and inhibiting the production of IL-4 and IL-5. Wei et al. [44] showed that the total extract of glycyrrhiza, flavonoids and saponins have anti-inflammatory and analgesic effects, and the flavonoids have the best effect through UPLC-QTOF-MS metabonomics method.

Qu Xiaomei et al. [45] verified that the water extract of glycyrrhiza in mice could significantly inhibit the formation of granuloma and toe swelling in mice through the mouse xylene ear swelling model and the egg white-induced toe swelling model, indicating that the water extract of glycyrrhiza Has antiinflammatory effects. Wu Minman et al. [46] proved through experiments that aqueous extract of glycyrrhiza can hinder the 
metabolism of arachidonic acid and inhibit the release of histamine from mast cells, which has a significant anti-inflammatory effect. Dong Jinxiang et al. [47] studied the regulation of Gansu wild glycyrrhiza endophyte fermentation broth and host decoction, total flavonoids, and total saponins on lipopolysaccharide LPS-stimulated mouse macrophage (raw264.7) cell inflammation model secretion of inflammatory factors The results showed that the fermentation broth of glycyrrhiza endophytes JTYB018 and JTYF027 can inhibit raw264.7 secreting NO, TNF-a, and IL6 . Research by Wang Liyao et al. [48] showed that the compound licostilbene $B$ derived from glycyrrhiza can inhibit the phosphorylation of p65 subunits, ERK, JNK, and p38 proteins, thereby inhibiting the activation of NF-KB and MAPKs pathways induced by LPS and exerting anti-inflammatory effects. effect.

Zhao Yunsheng et al. [49] studied the effects of different doses of glycyrrhiza polysaccharides on acute inflammation in mice, and found that the high-dose group $(10 \mathrm{mg} / 10 \mathrm{~g})$ and the low-dose group ( $3 \mathrm{mg} / 10 \mathrm{~g}$ ) of glycyrrhiza polysaccharides had the inhibition rate on mouse abdominal cavity capillary permeability $38.95 \%$ and $15.41 \%$ respectively, indicated that glycyrrhiza polysaccharide has a significant inhibitory effect on acute inflammation in mice. Tanaka et al. [50] analyzed the volatile oil components in glycyrrhiza roots by gas mass spectrometry, which were mainly aldehyde and caproic acid, and measured its anti-inflammatory activity by ELSA kit, and found that the volatile oil components had strong anti-inflammatory activity. Liu Yuanyuan et al. [51] used UPLC-QTOF-MS metabonomics method to analyze the pharmacodynamic mechanism of Gancao Fuzi Decoction. The alkaloids, flavonoids and saponins in Gancao Fuzi Decoction treat arthritis by regulate amino acid metabolism, energy metabolism, intestinal metabolism and metabolism of intestinal flora. Wei et al. [52] found that the total extract of glycyrrhiza, flavonoids and saponins have antiinflammatory and analgesic effects through the metabonomics method of UPLC-QTOF-MS, which the flavonoids have the best effect. Zhao Jie et al. [53] have shown that ephedra-glycerin can significantly inhibit carrageenan-induced pleural fluid exudation and increase in the number of white blood cells in the inflammatory area, indicating that it can inhibit inflammation and the adhesion and aggregation of inflammatory cells, and has a good anti-inflammatory effect/. It can be seen that glycyrrhiza extract is closely related to the body's anti-inflammatory, and can be used as an ideal source of potential anti-inflammatory drugs.

\subsection{Antivirus}

The antiviral mechanism of glycyrrhiza polysaccharide may be achieved by enhancing the activity of immune cells and enhancing the ability of antigen-presenting cells to swallow pathogenic microorganisms [54]. The study of He Dan et al. [55] showed that glycyrrhiza extract could induce the function of glycoprotein (P-gp) and up-regulate its expression, thereby promoting P-gp-mediated efflux of intracellular toxins to achieve antiviral effects. Glycyrrhizic acid can inhibit viral replication and has a good antiviral effect on the treatment of hepatitis $B$ virus, HIV, SARS virus, etc. [56]. The mechanism of glycyrrhizic acid inhibiting HIV replication is mainly to reduce the activity of protein kinase $C$ and can effectively prevent the spread of HIV. Glycyrrhizic acid can also inhibit and reduce the activity of DNA synthesis rate-limiting enzymes and nucleotide reductases to hinder the migration of tumor cells during the synthesis phase, thereby allowing cancer cells to differentiate and inhibit cancer cell proliferation[2] . Song et al. [57] isolated 28 triterpene sapo- nins from glycyrrhiza root and tested them for anti-H1N1 and anti-HIV activities. The results showed that uralsaponins M/S/T and $22 \beta$-acetoxyglycyrrhizin have strong anti-H1N1 activity. Its ICso values are 48.0, 42.7, 39.6, and $49.1 \mu \mathrm{M}$ respectively. $22 \beta$ acetoxyglycyrrhizin and 3-O- $\beta$-D-Glucuronopyranosylglycyrrhetinic acid have strong activity against HIV, and their ICso values are 29.5 and $41.7 \mu \mathrm{uM}$ respectively. The compounds of oleic acid, dehydrocrural glycyrrhizin D and glycyrrhetinic acid extracted from glycyrrhiza have good inhibiting effects on streptococcus mutans, staphylococcus aureus, methicillin-resistant staphylococcus aureus, quinolone-resistant staphylococcus aureus and bacillus subtilis. The minimum inhibitory concentration of the inhibitory effect is $16-32 \mu \mathrm{g} / \mathrm{mL}, 8-16 \mu \mathrm{g} / \mathrm{mL}$ and 32 $64 \mu \mathrm{g} / \mathrm{mL}[58]$. Glycyrrhizol extract has a good antibacterial effect on Gram-positive bacteria, and its minimum inhibitory concentration is $1.25 \mathrm{mg} / \mathrm{ml}$ [59].

\subsection{Lowering blood sugar and blood lipids}

DushkinM [60] et al. reported that the ethanol extract of glycyrrhiza can reduce the blood glucose level of rats fed highfat diet, and can improve their glucose tolerance. Zhao Haiyan et al. [61] have shown that glycyrrhiza flavonoids can reduce the blood sugar level of diabetic rats, and can also regulate lipid metabolism disorders. The total flavonoids of glycyrrhiza have the effect of reducing hyperlipidemia in hyperlipidemia model rats induced by high-fat diet. Its mechanism of action may be through increasing the expression of PPARa protein molecules, thereby increasing the expression of adenosine monophosphate activated protein kinase (AMPK) and p-AMPK protein molecules to achieve the effect of treating hyperlipidemia [62]. aglucosidase inhibitor is a new type of oral hypoglycemic agent, clinically used as the first choice for the treatment of type 2 diabetes, and an auxiliary drug for type 1 diabetes. Zeng Lan et al. [63] first discovered and proved that the isoflavone compound in glycyrrhiza had a-glucosidase inhibitory effect, which provides a new way for the further development and utilization of glycyrrhiza. Peng Lei et al. [64] studied the hypoglycemic activity of ethanol extract of glycyrrhiza. The experimental results showed that ethanol extract of glycyrrhiza could reduce serum glycosylated hemoglobin, triglycerides, low-density lipoprotein, and total cholesterol content, and improve its oral glucose tolerance. And It could also increase the level of insulin in the serum to lower the blood sugar level of diabetic mice. Glycyrrhiza chalcone $E$ is a partial agonist of PPAR- $\gamma$, which can promote PPAR-y mRNA expression in white adipose tissue, reduce fat cell volume and promote preadipocyte differentiation, thereby improving insulin resistance and reducing dietary obesity diabetes blood glucose and blood lipids in mice [65].

\subsection{Protect the skin}

Zhao Weide [66] studied the effect of glycyrrhiza and salvia miltiorrhiza extraction ratio on the whitening activity of the extract, and the results showed that the glycyrrhiza and salvia compound extract could inhibit tyrosinase activity, resist ultraviolet radiation and reduce the production of melanin, promote metabolism and soften the role of the stratum corneum, and will not cause irritation to human skin.

Studies have shown that $5 \%$ glycyrrhiza extract aqueous solution for external use has a protective effect on ultraviolet-induced skin photoaging and cell apoptosis in mice. Its protective effect may be related to inducing the production of SOD, MDA, and TNF-a in skin tissues and reducing skin cell apoptosis [67]. G9315 is a mixture of 6 flavonoids extracted from 
glycyrrhiza inflata. $2 \mathrm{mg}$ skin application can significantly inhibit the formation of papilloma in mice induced by dimethylbenzanthracene (DMBA) combined with croton oil [16]. The study of Nerya [68] found that the isoglycyrrhizin in glycyrrhiza had an inhibitory effect on the tyrosinase monophenolase that synthesized melanin, and the inhibitory effect was dose-dependent. Therefore, they believe that chalcone flavonoids can be used as lead compound candidates for skin whitening agents.

\section{Application of glycyrrhiza in poultry production}

Wu Hua et al. [69] studied the effect of adding glycyrrhizae residues in the feed on the performance of broiler chickens, and found that compared with the control group, the addition of $3 \%$ glycyrrhizae residues group can significantly increase the daily gain of broilers and reduce feed weight gain ratio ( $P$ $<0.05)$, and can significantly increase the apparent metabolic rate of crude protein of the diet $(P<0.05)$. The addition of different levels of glycyrrhiza residue group can reduce the apparent metabolic rate of crude fat in the diet $(P<0.05)$. The study by Shao Qi et al. [70] showed that adding a proper amount of glycyrrhiza cream can significantly increase the antioxidant capacity in broiler serum. The antioxidant capacity of the $50 \mathrm{mg} / \mathrm{l}$ group was significantly higher than that of the $0 \mathrm{mg} / \mathrm{l}$ and 100 $\mathrm{mg} / \mathrm{l}$ groups $(P<0.05)$.

Yi Lei et al. [71] studied the effect of glycyrrhiza polysaccharides on the antioxidant activity of chickens. The drug group was injected intramuscularly with low $(1 \mathrm{mg} / \mathrm{mL})$, medium $(2 \mathrm{mg} / \mathrm{mL})$, and high $(4 \mathrm{mg} / \mathrm{mL})$ concentration of glycyrrhiza polysaccharide for $1 \mathrm{~mL}$. The results showed that glycyrrhiza polysaccharide could significantly improve the total antioxidant capacity of T-AOC, glutathione peroxidase GSH-Px and catalase CAT activities of Roman chickens $(P<0.05)$ ), and the highdose group had the best effect. The research results of Dong Yongjun et al. [72] showed that adding $1.0 \mathrm{~g} / \mathrm{kg}$ of glycyrrhiza polysaccharides to feed has a significant impact on the microflora of the animal's digestive tract, which can promote the proliferation of beneficial intestinal bacteria bifidobacterium and lactobacillus, and inhibit proliferation of harmful bacteria of of bacillus and salmonella in the large intestine. Wang Lirong et al. [73] studied the effect of glycyrrhiza polysaccharide on the antibody titer and body weight of Newcastle disease in chickens and found that glycyrrhiza polysaccharide had a certain effect on improving the immunity and weight gain of chickens. Grinding glycyrrhiza and its rhizomes as feed additives can improve the production performance and immune performance of Muscovy ducks, and increase the total protein, albumin and various indicators in the blood of Muscovy ducks [74]. Ma Lu et al. [75] studied the effects of adding different levels of glycyrrhiza polysaccharides in the diet on the immune function of broiler chickens. The results showed that the addition of glycyrrhiza polysaccharides in the diet could improve the immune organ index and Newcastle disease antibody of broilers to a certain extent. The level and the mass concentration of immunoglobulin, the mass concentration of cytokines and the gene expression level of spleen-related cytokines can improve the immune function of the body. Zhang Cai et al. [76] studied the effects of adding different levels of glycyrrhiza polysaccharides in the diet on the growth performance and serum biochemical indicators of broilers. The results of the study showed that the $500 \mathrm{mg} / \mathrm{kg}$ group and the $1,000 \mathrm{mg} / \mathrm{kg}$ group were added to the diet. glycyrrhiza polysaccharides can significantly increase the average daily gain (ADG) of 22-42-day-old broilers and reduce the feed-toweight ratio $(F / G)(P<0.05)$. And it can increase the mass concentration of total protein (TP) and globulin (GLB) in broiler serum and the concentration of high-density lipoprotein (HDL-C) $(P<0.05)$, and can significantly reduce alanine aminotransferase $(A L T)$ and glycerol The concentration of triester (TG) and uric acid (UA) $(P<0.05)$.

Chen Jingyi[77] et al. studied the effects of alternative products on the growth performance and immune function of broiler chickens, and the results showed that the glycyrrhiza extract group could significantly increase the weight of the chicks $(P<0.05)$, and the thymus and bursa of Fabricius in the glycyrrhiza extract group, newcastle disease (ND) antibody titer, avian influenza H9N2 antibody titer, IL-2 and IFN-y levels were significantly higher than those of the control group $(P<0.05)$. The above results all showed that the addition of glycyrrhiza extract in the diet could improve the production performance of poultry, immune function, reduce production costs, and improve economic benefits.

\section{Conclusions}

With the continuous improvement of living standards, people's awareness of health and the demand for animal products are also increasing. Glycyrrhiza has many functions such as anti-tumor, anti-inflammatory, anti-viral, liver protection, skin care, etc., and the residue of glycyrrhiza in animal products also has no side effects on the human body, and this makes glycyrrhiza get a widely attention. However, the active ingredients of glycyrrhiza, the best extraction process and the mechanism of disease resistance and treatment are not very clear, and they have not been widely used in livestock and poultry production, which limits the wide application of glycyrrhiza. Future research directions for glycyrrhiza:

1) Explore the mechanism of action of the active ingredients of glycyrrhiza extract in animal bodies.

2) Appropriate addition ratio of glycyrrhiza extract in the diet.

3) Further optimize the extraction process of glycyrrhiza.

4) Use the biologically active ingredients of glycyrrhiza extract to replace antibiotics in animal husbandry.

With the in-depth research on the effective chemical components, pharmacological effects and extraction technology of glycyrrhiza, the application value of glycyrrhiza will be further developed and comprehensively utilized, which will have a profound impact on the development of medical care and modern animal husbandry.

\section{References:}

1. Liu Qian, Li Xi. Using plant metabolomics technology to detect the content of active ingredients in glycyrrhiza from different origins[J]. Asia-Pacific Traditional Medicine, 2019,15(6):45-49

2. Xiang Jing. Research on the effect of glycyrrhiza miRNA on gene expression profile of human immune cells[D]. Guangdong Pharmaceutical University, 2017.

3. Deng Taomei, Peng Can, Peng Daiyin, Yu Nianjun, Chen Weidong, Wang Lei. Research progress on the chemical con- 
stituents and pharmacological effects of glycyrrhiza and discussion of quality markers [J]. Chinese Journal of Chinese Materia Medica, online first, 2021-03-08

4. Tian Wusheng. The chemical composition and clinical research overview of glycyrrhiza [J]. Clinical Research of Traditional Chinese Medicine, 2012, 4(16): 31-32.

5. Smith Peter Andrey. The tantalizing links between gut microbes and the brain.[J]. Nature, 2015, 526(7573) : 312-4.

6. Seon M R , Park S Y, Kwon S J, et al. Hexane/ethanol extract of Glycyrrhiza uralensis and its active compound isoangustone A induce G1 cycle arrest in DU145 human prostate and 4T1 murine mammary cancer cells[J]. Journal of Nutritional Biochemistry, 2012, 23(1):85-92.

7. Xu Shumei, Zhou Lei, Liu Zhuogang, Chen Bo, Li Yang. Glycyrrhetinic acid induces U266 cell apoptosis and its effect on Survivin expression[J]. Chinese Journal of Experimental Hematology, 2011,19(03):652-655 .

8. Lee CS,Kim YJ,Lee MS,et al. 18ß-Glycyrrhetinic acid induces apoptotic cell death in SiHa cells and exhibits a synergistic effect against antibiotic anti-cancer drug toxicity[J]. Life Sciences, 2008, 83(13-14):481-489.

9. Xiao $X Y$, Hao $M$, Yang $X Y$, et al. Licochalcone A inhibits growth of gastric cancer cells by arresting cell cycle progression and inducing apoptosis[J]. Cancer Letters, 2011, 302(1):69-75.

10. Chu X T, Cruz J D L , Hwang S G , et al. Tumorigenic effects of endocrine-disrupting chemicals are alleviated by glycyrrhiza (Glycyrrhiza glabra) root extract through suppression of AhR expression in mammalian cells.[J]. Asian Pacific Journal of Cancer Prevention Apjcp, 2014, 15(12):4809-13.

11. Yan Shu, Gu Dawei, Chen Zhimin, Zhou Ming, Shi Hui, Wang Yang, Wu Yuchen, Cai Yunqing. Glycyrrhizin inhibits the invasion and metastasis of human melanoma A375 cells by regulating miRNA[J]. Journal of Nanjing Medical University (Natural Science Edition) ), 2015, 35(02):263-269.

12. Yuxin $L$, Sirou X, Yu W , et al. Liquiritigenin Inhibits Tumor Growth and Vascularization in a Mouse Model of Hela Cells[J]. Molecules, 2012, 17(6):7206-7216.

13. Wang Y, Xie S, Liu C, et al . Inhibitory Effect of Liquiritigenin on Migration Via Downregulation ProMMP-2 and PI3K/Akt Signaling Pathway in Human Lung Adenocarcinoma A549 cells[J]. Nutrition \& Cancer, 2012, 64(4):627-634.

14. Ma J , Fu N Y , Pang D B , et al. Apoptosis induced by isoliquiritigenin in human gastric cancer MGC-803 cells.[J]. Planta Medica, 2001, 67(08):754-757.

15. Wang Cunliang. Anti-tumor effect of combination of glycyrrhiza flavonoids and cyclophosphamide[J]. Chinese Journal of Hospital Pharmacy, 2011(22):1877-1880.

16. Tao Yuzhu. Study on the effects of Codonopsis pilosula and glycyrrhiza extracts on the signal pathway of IEC-6 cell migration polyamine regulation [D]. Guangzhou University of Traditional Chinese Medicine, 2013.

17. Si-Rou, Xie, Yu, et al. Liquiritigenin Inhibits Serum-induced HIF-1a and VEGF Expression via the AKT/mTOR-p70S6K Signalling Pathway in HeLa Cells[J]. Phytotherapy Research, 2011.

18. Zhang Yiping. Research on mechanism of glycyrrhizin biotransformation and prevention and treatment of tumors and chronic liver injury[D]. 2016.

19. Hong Y K, Wu H T, Ma T, et al. Effects of Glycyrrhiza glabra polysaccharides on immune and antioxidant activities in high-fat mice[J]. International Journal of Biological Macromolecules, 2009, 45(1):61-64.

20. Kang Jinsen, Cheng Lufeng, Yang Jian, Tao Yicun, Hu Jian. The effect of total flavonoids of glycyrrhiza on skin aging[J]. Shandong Medicine, 2012, 52(42): 34-35.

21. Sun Guoqing, Luo Zhengli. Anti-aging effect of glycyrrhizin on aging model rats[J]. Chinese Journal of Gerontology, 2014, 34(07): 1895-1896.

22. Lian Yijun, Liu Hong, Ma Yanmei, Sun Ping, Li Bingqi. Study on the separation, purification and antioxidant activity of polysaccharides from glycyrrhiza residue with macroporous resin[J]. Journal of Shihezi University (Natural Science Edition), 2015, 33(03) ):351-356.

23. Chang Jing. Study on the extraction, content determination and antioxidant activity of flavonoids in glycyrrhiza [D]. North University of China, 2014.

24. Xue Wei. Extraction, structure analysis and activity study of glycyrrhiza polysaccharides[D]. Tianjin University of Science and Technology, 2019.

25. Liu Jiao. Study on the effect of Dioscorea opposita with glycyrrhiza on oxidative stress and the expression of CYP1A2 and CYP2E1 protein in rat liver[D]. Fujian University of Traditional Chinese Medicine, 2014.

26. Kim Y W , Kim Y M , Yang Y M , et al. Inhibition of LXRa-Dependent Steatosis and Oxidative Injury by Liquiritigenin, a glycyrrhiza Flavonoid, as Mediated with Nrf2 Activation.[J]. Antioxidants \& Redox Signaling, 2011.

27. Hu Huiping. Research progress on the antiviral effects of glycyrrhiza[J]. China Journal of Traditional Chinese Medicine, 2004, 15(8): 6-10.

28. Shen Qiaofeng. Comparison of the efficacy of different glycyrrhizic acid drugs in the treatment of chronic hepatitis $B[J]$. Strait Pharmacy, 2012, 24(07):101-103.

29. Wu Chengjiu. Observation on the curative effect of compound glycyrrhizin on chronic hepatitis B[J]. China Journal of Modern Medicine, 2012, 14(10): 25-27.

30. Liu Hualong. Study on the efficacy of compound glycyrrhizin in the treatment of chronic hepatitis B against liver fibrosis[J]. Journal of Clinical Rational Use, 2012, 5(24): 10-11.

31. Zhao Fei, Zhang Fengbin, Zhou Yonghong, Zhang Li, Wang Yingying, Zhang Ruixing. Observation on the effect of diammonium glycyrrhizinate on liver injury induced by carbon tetrachloride in rats[J]. Liver, 2012, 17(02): 115-117 .

32. Renjie L, Shidi S, Changsen S. Protective effect of Glycyrrhiza glabra polysaccharides against carbon tetrachloride- 
induced liver injury in rats[J]. African Journal of Microbiology Research, 2010, 4(16):1784-1787.

33. Chen Yunhua, Wan Xin, Sun Jianning, Wang Wenquan, Zhang Shuofeng. Comparison of the protective effects of glycyrrhizic acid, glycyrrhizin, and isoliquiritin on acetaminophen human liver cell injury model[J]. Chinese Journal of Experimental Prescriptions, 2012, 18 (04):245-248.

34. Jing Jing. Research on the Intervention Effect and Mechanism of Total Flavonoids of glycyrrhiza on Non-alcoholic Fatty Liver[D]. Ningxia Medical University, 2015.

35. Huang Qunrong, Ma Zhe. Research progress on the pharmacological effects of glycyrrhizic acid[J]. Drug Evaluation Research, 2011, 34(05):384-387.

36. Liu Liping, Ren Cuiai, Zhao Hongyan. Research progress in the immunomodulatory effects of glycyrrhizic acid[J]. Chinese Journal of Experimental Formulas, 2010, 016(006):272-276.

37. Li Entao. Preparation of glycyrrhiza Polysaccharide Liposomes and Study on Its Immunoenhancing Effect[D]. Nanjing Agricultural University, 2016.

38. Wang Lirong, Li Jie, Dong Yongjun, Hang Bolin, Liu Xingchang. The effect of glycyrrhiza polysaccharides on the growth performance and cellular immunity of mice[J]. Northwest Agricultural Journal, 2007(01): 220-222.

39. Hong Y K, Wu H T, Ma T, et al. Effects of Glycyrrhiza glabra polysaccharides on immune and antioxidant activities in high-fat mice[J]. International Journal of Biological Macromolecules, 2009, 45(1):61-64.[J].Agricultural Science \& Technology,2008(02):129-131.

40. Li Fasheng, Zhao Jue, Chi Xiaofeng, Yang Bo, Yan Xiaomei, Liu Hairi. The effect of glycyrrhiza polysaccharide on immune regulation in mice[J]. China Journal of Information on Traditional Chinese Medicine, 2009, 16(06): 35-36 .

41. Xu Pengcheng. The effect of glycyrrhiza and its miRNA on the intestinal flora and immunity of mice [D]. Guangdong Pharmaceutical University, 2018.

42. Guo Ao. glycyrrhiza and its components promote the production and function of Treg cells and the observation of Mphase haploid stem cells[D]. University of Science and Technology of China, 2016.

43. Ji-Yeon Kim,Seung Jae Park,Kyung-Jin Yun,Young-Wuk Cho,Hee-Juhn Park,Kyung-Tae Lee. Isoliquiritigenin isolated from the roots of Glycyrrhiza uralensis inhibits LPS-induced iNOS and COX-2 expression via the attenuation of NF-KB in RAW 264.7 macrophages[J]. European Journal of Pharmacology,2008,584(1).

44. Mengying Wei,Yinghui Ma,Yuanyuan Liu,Yuan Zhou,Lihui Men,Kexin Yue,Zifeng Pi,Zhiqiang Liu,Zhongying Liu. Urinary metabolomics study on the anti-inflammation effects of flavonoids obtained from Glycyrrhiza.[J]. Journal of Chromatography B,2018,1086.

45. Qu Xiaomei, Jin Zhongtai, Shang Yanhua, Cai Yan. Experimental study on the anti-inflammatory effect of glycyrrhiza decoction[J]. Practical Medicines and Clinics, 2005(05): 14-16.

46. Wu Minman, Guo Zhaogang. Experimental study on the prevention and treatment of allergic rhinitis with glycyrrhiza extract[J]. Chinese National Folk Medicine, 2010, 19(05): 37-39.

47. Dong Jinxiang, Deng Yi, Liu Liang, Zhao Ni, Man Qiong, Wu Guoxia, Yang Zhijun. Effects of Gansu wild glycyrrhiza endophyte fermentation broth and host decoction, total flavonoids, and total saponins on the secretion of inflammatory factors in raw264.7 induced by LPS Influence[J]. Northern Pharmaceutical Sciences,2016,13(07):137-138.

48. Wang Liyao. Study on the chemical constituents of the ethyl acetate part of Glycyrrhiza Uralensis leaves[D]. Lanzhou University, 2020.

49. Zhao Yunsheng, Mao Fuying, Zhao Qipeng, et al. Research on the anti-inflammatory and anti-gastric ulcer effects of glycyrrhiza polysaccharide [J]. Asia-Pacific Traditional Medicine,

2015, 11(9): 12-14.

50. Tanaka A, Shibamoto T. Antioxidant and Antiinflammatory Activities of glycyrrhiza Root( Glycyrrhiza uralensis ): Aroma Extract[J]. Acs Symposium Series, 2009, 993: 229-237.

51. Liu Yuanyuan. Pharmacodynamics and metabonomics of Gancao Fuzi Decoction in the treatment of rheumatism[D]. Jilin: Jilin University. 2016.

52.Wei M Y, Ma Y H, Liu Y Y, et al. Urinary metabolomics study on the anti-inflammation effects of flavonoids obtained from Glycyrrhiza[J]. Journal of Chromatography B Analytical Technologies in the Biomedical \& Life Sciences, 2018, 1086: 1-10.

53. Zhao Jie, Yu Linzhong, Fang Fang, Xu Wenjie, Luo Jiabo. Research on the anti-inflammatory effect and mechanism of ephedra-glycerin herb on [J]. Chinese Journal of Experimental Formulas, 2012, 18(15): 163-166.

54. Sun Xiangyang, Deng Yi. Overview of the main pharmacological effects of glycyrrhiza polysaccharides[J]. Chinese community physician (medical specialty),2011,13(24):179-180.

55. He Dan. The effect of glycyrrhiza extract and its three main components on the function and expression of P-gp on Caco2 cell membrane [D]. Central South University, 2010.

56. Sun Yun, Ainuer Wumaier, Yan Xuehua, Zhao Hu. Research progress on extraction methods and pharmacological effects of glycyrrhiza flavonoids[J]. Xinjiang Traditional Chinese Medicine, 2009, 27(01): 72-75.

57. Song Wei,Si Longlong,Ji Shuai,Wang Han,Fang Xiao-mei,Yu Li-yan,Li Ren-yong,Liang Li-na,Zhou Demin,Ye Min. Uralsaponins M-Y, antiviral triterpenoid saponins from the roots of Glycyrrhiza uralensis.[J]. Journal of natural products,2014,77(7).

58. Liu Yi. Study on the antibacterial activity of glycyrrhiza extracts and effective ingredients[D]. Yanbian University, 2013.

59. Zhang Yujiong, He Yanli, Li Hongwen. Study on the antibacterial activity and stability of alcohol extract of glycyrrhiza[J]. Jiangsu Traditional Chinese Medicine,2012,44(08):68-70.

60. Dushkin M, Khrapova M , Kovshik G, et al. Effects of rhaponticum carthamoides versus glycyrrhiza glabra and punica granatum extracts on metabolic syndrome signs in rats[J]. BMC Complementary and Alternative Medicine,14,1(2014-01-20), 2014, 
14(1):33-33.

61. Zhao Haiyan, Wang Yong, Wu Liwu, Ma Yongping. The effect of glycyrrhiza flavonoids on blood glucose and blood lipids in type 2 diabetic rats [J]. Chinese Journal of Diabetes, 2012, 20(01): 65-69.

62. Hua Bing. Research on the effect and mechanism of glycyrrhiza total flavonoids in lowering blood lipid[D]. Ningxia Medical University, 2015.

63. Zeng Lan. Extraction, purification and structure study of a-glucosidase inhibitor in glycyrrhiza [D]. South China University of Technology, 2012.

64. Peng Lei. Study on the structural modification and biological activity of glycyrrhetinic acid[D]. Jilin Agricultural University, 2016.

65.Park HG,Bak EJ,Woo GH,et al. Licochalcone E has an an-tidiabetic effect [J].J Nutr Biochem, 2012, 23(7):759-767.

66. Zhao Weide. Study on the extraction, evaluation and application of active ingredients in glycyrrhiza and salvia miltiorrhiza[D]. Nanjing University of Science and Technology, 2016.

67. Bian Fang. Preliminary exploration of protective effects of water extracts such as glycyrrhiza on UVB-induced skin photoaging in BALB/c mice[D]. Lanzhou University, 2011.

68. Nerya $\mathrm{O}$, Vaya J, Musa R, et al. Glabrene and isoliquiritigenin as tyrosinase inhibitors from glycyrrhiza roots.[J]. J Agric Food Chem, 2003, 51(5):1201-1207.

69. Wu Hua, Zhang Hui, Duan Qihui. The effect of glycyrrhiza residue on the quality of grazing broiler chicken[J]. Journal of Qinghai University (Natural Science Edition), 2010, 28(03): 58-61.

70. Shao Qi, Zhang Cai, Niu Yale, Zhang Xianmin, Wang Hongwei, Wang Jicang, Yang Zijun. The effect of glycyrrhiza cream on growth performance and antioxidant capacity of broilers[J]. Feed Industry, 2016, 37(08): 41-44 .

71. Yi Lei, Shi Yu, Liu Guang, Lin Luying, Wu Yi, Liu Jiaguo, Hu Yuanliang, Wang Deyun. Study on the antioxidant activity of glycyrrhiza polysaccharides in chickens[J]. Animal Husbandry and Veterinary Medicine, 2019, 51(02): 110- 113.

72. Dong Yongjun, Wang Lirong, Qi Yonghua, An Zhixing, Yao Sixin, Liu Xingyou. Study on the regulation of glycyrrhiza polysaccharides on the intestinal microbes of broilers[J]. Food and Feed Industry, 2012(04): 47-49.

73. Wang Lirong, Dong Yongjun, Hu Jianhe, Wang Xianwen, Hang Bolin. The effect of glycyrrhiza polysaccharide on the antibody titer and body weight of Newcastle disease in chicks[J]. Northwest Agricultural Journal, 2011, 20(06): 55-57.

74. Zhang Rui, Zhao Jinghui, Wang Yingping, Yan Meixia, Liu Hongqun, Chen Shaolin. glycyrrhiza residues and stems and leaves of Atractylodes radiata affect the production performance and immunity of Muscovy ducks

75. Ma Lu, Zhang Cai, Yang Zijun, Li Chenxu, Chen Wenbin, Dai Jingjing, Ma Yanbo, Liu Yan. The effect of glycyrrhiza polysaccharide on the immune function of broilers[J]. Chinese Veterinary Science, 2020, 50(09):1198- 1206.

76. Zhang Cai, Ma Lu, Yang Zijun, Dai Jingjing, Ma Yanbo, Liu Yan, Wang Guoyong. The effect of glycyrrhiza polysaccharides on growth performance and serum biochemical indexes of broilers[J]. Journal of Henan University of Science and Technology (Natural Science Edition), 2021,42(02):88-93+9-10.

Бордунова Ольга Георгіївна', доктор сільськогосподарських наук, профессор

Вечорка Вікторія Вікторівна', доктор сільськогосподарських наук, профессор

Лю Чанчжун, доктор сільськогосподарських наук, профессор, Хенаньський науково-технічний інститут Китаю

Кисельов Олександр Борисович 1 , кандидат сільськогосподарських наук, доцент,

Самохіна Євгенія Анатоліївна', кандидат сільськогосподарських наук, доцент

${ }^{1}$ Сумський національний аграрний університет (Суми, Україна)

Особливості застосування екстракту glyсуrrhiza у птахівництві

У статті наведені дослідження впливу фітогенних препаратів на імунну систему та продуктивність сільськогосподарських тварин. Аналізуючи світову тенденцію щодо зацікавленості фітогенними рослинними препаратами, в статті представлені дослідження найбільш популярного препарату - glycyrrhiza. Даний преnарат - це один з компонентів традиційних китайських лікувальних засобів. Glусугrhiza має властивості бадьорості ци, використовується для профілактики роботи селезінки, має відхарклювальні властивості та сприяє полегшенню кашлю, діє як жарознижуюче, використовується при детоксикації, при цьому сумісний з багатьма лікарськими препаратами. Традиційно даний препарат використовували для профрілактики й лікування людини - як протипухлинні, протизапальні, противірусні засоби, також використовували для догляду за шкірою. Відомо, що залишки glyсугrhiza в продуктах тваринного походження не мають побічної дії на організм людини, і цей факт ще більше привертає увагу до більш широкого використання glyсугrhiza в сучасному тваринництві. Однак, деякі активні компоненти glyсугrhiza, на цей час вивчені не до кіния. Також вивчається процес екстракції. Механізм стійкості до хвороб і лікування даним препаратом, на сьогоднішній день, не дуже зрозумілі. Внаслідок чого, препарат не отримав широкого поширення в тваринництві та птахівництві. Glyсуrrhiza містить тритерпенові сапоніни, фрлавоноїди, полісахариди та інші корисні для організму біологічно активні речовини. Має унікальний комплекс властивостей, таких як: антиоксидантної, антибактеріальної, противірусної, протипухлинної, протизапальної, а також має здатність до регуляції імунної та біологічної активності організму, контроль рівня цукру в крові - все це і привертає увагу до себе.

У статті розелядається хімічний склад, механізм дії і застосування glycyrrhiza в птахівниитві. Основна мета дослідження - сформулювати рекомендації щодо застосування екстракту glyсугrhiza в птахівництві.

Ключові слова: екстракт гліциризу, фітогенні препарати, антиоксидант, антибактеріальний, противірусний, протипухлинний, протизапальний, продуктивність, птахівництво.

Дата надходження до редакції: 13.04.2021 p. 